\title{
The Peace Accord, Cross-Community Programs and the Implications of the British Exit (Brexit)
}

\author{
Eileen Frances-McInerney Starr \\ Metropolitan State University-Denver
}

On June $23^{\text {rd }} 2016$ the United Kingdom voted to leave the European Union. However, Northern Ireland voted to remain, substantiating old divisions. Protestants voted to leave and Catholics voted to stay. This article will discuss the implications of Brexit to the 1998 Peace Accord and cross community programs in Northern Ireland, specifically the Ulster Project (UPI). UPI was created to increase religious, social, and political tolerance for differing religions and cultures, as well as foster increased good will between Protestants and Catholics. Brexit will have significant implications to the work of cross-community programming and the 1998 Peace Accord.

Keywords: Brexit, Identity, Nationalists/Catholics, The Other, Peace Process, Peace Walls, The Troubles, Unionists/Protestants, Ulster Project

\section{INTRODUCTION}

The historically contested six counties in Northern Ireland, has experienced multi-generational conflict since the 1600's when the Protestant King William III defeated the Catholic King James II. However, the focus is on the most recent era known as the "Troubles." The Troubles reflect the conflicts between national, cultural, and religious identities of Protestants, also known as Unionists who identify as British, and Catholics, also known as Nationalists who consider themselves Irish. Many of the Catholics wish for a united Ireland, while many Protestants recoil at this idea (Archick, 2019). This conflict actively occurred between the late 1960s through the late 1990s, claiming more than thirty-five hundred lives and injuring countless others. A peace deal, known as the Good Friday Agreement or the Belfast Peace Accord (GFA/BPA) was signed 1998. The peace agreement created a power-sharing government called the Northern Irish Assembly (NIA) that included Sinn Féin, the Nationalists' political representation connected to paramilitary groups. Many view the 2007 power sharing deal between the Protestant Democratic Unionist Party (DUP) and Catholic Sinn Féin, the political arm of the Irish Republican Army (IRA), within the NIA as the main success of the peace accord. Despite this success, distrust persists between the two groups and their communities (Archick, 2019). Intermittent sectarian violence continues to flare up, especially around historic celebrations. These historic celebrations include the July 11th bonfires in Unionists' neighborhoods which are condemned by Nationalists for displays of sectarian and ethnic hatred leading up to the July $12^{\text {th }}$ parades. The July $12^{\text {th }}$ parades celebrate the Protestant King William of Orange over the Catholic King James II in the Battle of the Boyne in 1690 (https://www.bbc.com, 2018). Unionists' supporters contend these celebrations are an integral part of 
their heritage and culture. Due to the predictable nature of the clashes, every July $11^{\text {th }}$ and $12^{\text {th }}$, on-going and historical mistrust and sectarian discord continues to be fueled, resulting in violent outbursts.

\section{THE ULSTER PROJECT}

One of the cross-community integration programs to mitigate the influence of community violence on adolescents' is The Ulster Project, founded by Reverend Kerry Waterstone, an Anglican priest for The Church of Ireland (Ulster Project International, 2019). The Ulster Project was formed in 1976 in efforts to interrupt the effects of The Troubles. Reverend Waterstone felt that participation effectuated positive influences on the Protestant and Catholic Northern Irish participants (Ulster Project International, 2019). These influences included increased religious, social, and political tolerance between the two Christian denominations, resulting in goodwill, diminished negative stereotyping, and increased cross-community interaction (Ulster Project International, 2019). The primary goal of the Ulster Project is to promote reconciliation between opposing groups by fostering tolerance, understanding and friendships between members of different faiths (Ulsterproject 2019). It was anticipated that, because of their experiences participants might influence the future in Northern Ireland.

\section{Context}

For the past 98-years (3 May 1921) Ireland has been divided. The six counties in the north of the island are part of the United Kingdom (UK) while the 26 counties in the south of the island are part of the independent nation, the Republic of Ireland. Despite multiple peace agreements, sectarian violence, and "othering," divisiveness continues. During the reenactment period in July, traditions dating back to the 17 th century exacerbate the dissention. Long held cultural values and historical trauma reinforce division and violence. Despite multiple agreements for peace and disarmament between Protestant and Catholic paramilitary organizations, sectarian violence is ubiquitous and overarching in Northern Ireland. Paramilitary organizations include the various factions of the IRA and Protestant paramilitary groups. The 2017 dissolution of the Northern Irish Assembly (NIA) left no governing body. The NIA is the shared governance created as part of the peace agreement. This disbanding exacerbated the looming anxiety about the implications of Brexit, heightening the sense of divisiveness, tribalism, and subsequent community violence. Brexit, (short for British Exit) is the term used to describe the forthcoming plan for the UK to leave the European Union (EU). In the late 1960's, the latest wave of The Troubles was incited when Catholics, who had experienced historical discrimination in areas such as electoral rights, housing, and employment, launched a civil rights movement. Some Unionist paramilitary and the police met this civil rights movement with violence. As a result, armed action erupted between Nationalists and Unionists. The increasing chaos and escalating violence led the UK government to deploy the British Army on the streets in 1969, imposing direct rule from London (Archick, 2019). The deployment of the British Army further exacerbated the conflict, due to the historical role of the British military suppressing the actions of individuals who protested the UK's presence on their soil.

Catholics/Nationalists and Protestants/Unionists Northern Ireland inhabitants use the terms Catholic (Nationalists) and Protestant (Unionists), to designate sides of the political conflict rather than merely doctrinal differences within the Christian faith. The term Catholic in Northern Ireland, designates one who is of the indigenous (Gaelic) Irish population. The term also refers to a member of a minority group, which has historically been discriminated against in Northern Ireland. Catholic also indicates the desire to preserve the ancient Irish heritage and unite the six counties of Northern Ireland with the twenty-six counties making up the Republic of Ireland. Protestant refers to those who remain loyal to their ScottishBritish roots. Protestants are still labeled as foreigners by the indigenous Irish even though their families may have lived in Ireland for centuries. Protestant also refers to a member of the ruling class. Protestants seek to preserve their heritage by keeping Northern Ireland as part of the UK (Ulster Project International, 2019).

In the United States, a sub-identifier for social class, positionality, privilege, and power is typically race. The Northern Irish sort by being either Catholic or Protestant, British or Irish, and valuing a united 
Ireland or home rule. Interestingly, identifiers such as what sports teams' one participates in or follows, school one attends, supporting Palestine or Israel in their conflict, which housing area in the town one lives classifies one as being "for or against." As a result, identifiers such as wearing a jersey from a particular sports team, colors of the Union Jack or the tri-color flag of the Republic is strongly discouraged outside of one's area and could prove harmful. The Catholic/Protestant division creates a significant barrier to cross-community contacts. In fact, there are more peace walls in Northern Ireland than there were during the height of the Troubles. (Little, 2011) Peace lines, also known as a peace walls are physical barriers between the Protestant/Loyalist communities and the Catholic/Nationalist communities in certain areas in Northern Ireland (Dunn \& Dawson, 2000). Despite hopes raised by the 1998 Good Friday Peace Accord/Belfast Accord, political agreement continues to remain ambiguous and relations strained. The 1998 Peace Accord sought to clarify the relationships between Protestants and Catholics within Northern Ireland, between Northern Ireland and the independent Republic of Ireland, and between Northern Ireland and the rest of the UK (BBC News, 2019). Omnipresent violence functions as a political tool of extremists on both sides, barring overall acceptance of the quest for diversity in all areas and long-term peace in Northern Ireland.

The power-sharing governing agency, The Northern Irish Assembly (NIA), an outgrowth of the peace agreement, failed in 2017 because of long-standing disagreements between the Democratic Unionist Party (Unionists) and Sinn Féin (Nationalists). Unfortunately, all attempts to restore the NIA have since failed. The timing for Northern Ireland's lack of a formal government coincides with the significant implications of Brexit (Kelly, 2019). Citizens, especially Nationalists are concerned and unclear about the implications of Brexit, which may include a return to hard borders between the Republic of Ireland and Northern Ireland due to the six counties being a part of the UK, under British rule. Given that the division of the island has contributed to centuries of conflict, the growing concern is understandable.

In addition to Brexit being a contentious issue dividing Unionists and Nationalists there is also the on going "flag issue." Debates about flags continues to be [another] antagonistic issue for almost as long as there has been a Northern Ireland (Fenton, 2015). Unionists prefer the British Union Jack, prominent throughout "their" streets and neighborhoods, painting their curbs red, white and blue stripes. These conspicuous displays butt up to the Catholic neighborhoods and streets that perceive the spectacles as provocative, offensive and profane. This is even more apparent throughout the summer months, especially during the month of July during the approach of marching season. It is during this time when the bonfires and the annual Orange Order parades occur all through Northern Ireland.

The (Unionist) Orange Order is a fraternal organization named for King William III who defeated the Catholic King James II during the Battle of the Boyne (bbc.com, 2012). The "Orangemen" as they are known have lodges throughout Northern Ireland. Members identify themselves by wearing orange sashes. King William III is revered and seen as securing the rise of Protestantism in Ireland. (bbc.com, 2012). On the day of the parades, the participants and spectators integrate the Union Jack scheme everywhere and anywhere they can (Fenton, 2015). For Protestants, the UK flag is symbolic of Northern Ireland's Britishness and being a member of the United Kingdom. However, for Catholics, the flag is a symbol of intimidation and fear, similar to the Confederate Flag in the United States (Fenton, 2015).

\section{ADOLESCENCE AND CROSS-COMMUNITY INFLUENCES}

Research indicates that primary conflict during adolescence influences personal and social identity (Coon and Mitterer, 2009). Shepard (2007) determined that exposure to long-term violence and community discord impairs development and increases psychiatric symptomology. According to Merrilees, et al (2013) youth exposure to sectarianism is linked with increases in aggression and delinquent behaviors. Biological processes such as brain pruning also occurs in adolescence. Scientists propose the purpose of pruning is to facilitate the brain's ability to quickly assess and respond to the individual's environment, thereby maximizing a person's responsiveness. Social information processing theorizes that this iterative process of being shaped by our experiences and environment causes us to respond based on our previous experiences which then shapes the environment, ad infinitum (Crick \& 
Dodge, 1996; Lemerise \& Arsenio, 2000). Given the breadth of brain pruning occurring in adolescence, the individual's environment shapes the brain, which directly influences how they perceive and interact in their environment. It is through this phenomenon that an adolescent's experiences shape their understanding of their world and their subsequent reactions as adults. As a result, adolescents are particularly vulnerable to the effects of sectarian violence as both victims and perpetrators. Paramilitary groups recruit children, mostly males, as young as ten years of age. The rationale for recruiting young people into paramilitary organizations (by both sides) is considered to be politically motivated by the need to defend their community from outside threats, and therefore legitimate (Smyth \& Campbell, 2005).

To mitigate the collateral damage of The Troubles, cross-community organizations provided interventions, in an effort to decrease violence, while increasing goodwill, tolerance, and more positive perceptions of the Other, (a term used to identify individuals perceived by the group as not belonging, being different in some fundamental way). Cross-community groups often hold a narrow middle ground between Catholics and Protestants, critically decreasing tensions. Despite potential risks, some Catholics and Protestants continue contact with each other due to the friendships made because of their cross community group experiences. As a result, these 'mixed' relationships often work to discount divisive rhetoric and challenge inaccuracies and stereotypes. While these types of relationships may not have a direct impact on ultimate resolution of conflict, they may potentially control the intensity of the conflict through cross-community connections and relationships (Smyth \& Campbell, 2005).

\section{OPERATIONALIZING THE ULSTER PROJECT}

During the summer for approximately five weeks, Northern Ireland adolescents travel to 19 different American cities and towns, staying with preselected host families based on similar adolescent ages, religious denomination, and gender of the participating American adolescent (Ulsterproject.org, 2019). During this time, the Northern Irish and American adolescents and families participate in a variety of activities designed to foster friendship, tolerance and understanding. The activities include the following: service projects, professional sporting events, tours of historical sites, interfaith worship, social events that facilitate cross cultural interaction and team building (Ulsterproject.org, 2019). Additionally, specific to the Northern Irish youth, overnight retreats, known as "lock-ins," promote more intense discussions about their home communities and conflicts. During their time together, they examine issues including group memberships (e.g., paramilitary and segregated groups) and engage in community team building, creating unity. Concurrently, participants focus on their own strengths and history to know and understand themselves better, which is a necessary first-step in knowing the Other (Ulster Project.org., 2012). Activities and team building promote trust, interdependence, cross-cultural exposure, which are all critical elements. These elements underscore the serious nature of the Project; they are its raison d'être.

The Ulster Project focuses on five goals:

- To promote reconciliation between Northern Irish Catholics and Protestants by fostering tolerance, understanding, and friendship among teenage future leaders;

- To present a program that brings Northern Irish teens of differing Christian faiths together in a strife-free atmosphere that emphasizes acceptance of all people, regardless of creed;

- To educate and encourage persons, particularly supporters, committee members, and American Host Families, to appreciate their roles as peacemakers and mediators and to understand the purposes of Ulster Project;

- To encourage Northern Irish leaders and clergy involved in the program to continue to foster the spirit of Ulster Project among the Northern Irish participants following each program;

- To promote a spirit of community and commitment among American Ulster Project participants (Ulster Project.org., 2019). 


\section{Exploring the How and Why Questions}

Reflection and introspection nurture the emotional and cognitive work that is the essence of the Ulster Project. Adolescents explore the nature of prejudice and means to overcome it, while engaging in enjoyable activities, which lays the foundation toward trust, understanding, tolerance, and friendship (Ulster Project.org, 2019). Exploring humanistic 'how' and 'why' questions provides "illumination and understanding of complex psychosocial issues" (Marshall, 1996, p. 522). Participants join focus groups and further contribute to their perceptions of their participation in the Ulster Project via individual interviews. The groups and interviews articulate participants' experiences and recount impacts upon their views of the Other when they returned to Northern Ireland. Attitudinal changes encompass participants' reports of their personal tolerance, understanding, goodwill, enhancement of inter-group interaction, increased cross-community participation with those of differing faiths, and the impact on short and longterm attitudinal changes. An additional inquiry explores the participants' maintenance of relationships with other Northern Irish adolescents of differing faiths while in the program and post Ulster Project involvement. Capturing the subjects' description of their experiences align with a qualitative phenomenological framework.

Areas of inquiry concentrated on any attitudinal shifts in perceptions, and if so, what where the immediate shifts (if any) of Northern Irish adolescents who participate in the Ulster Project towards the Other? Another area of examination was, given the limited interaction with those of differing faiths, how do [did] Northern Irish participants perceive the Other prior to and after participation in the Ulster Project? Finally, how do [did] they make meaning of their experiences?

\section{Participants}

Subjects interviewed were involved beginning in the late 1970's through 2014. The focus groups $(n=10)$ and individual interviews $(n=31)$ presented opportunities to share retrospective knowledge of challenges encountered in Northern Ireland with regard to cross-community interventions. Many participants who were involved when the Ulster Project first began (in the 1970's) shared they now have children participating, a direct result of their experiences as adolescents. This provided data to understand longitudinal trends and the importance of interacting with the Other. Furthermore, the in-depth interviews allowed for a deeper understanding of the extent these experiences encouraged participants to demonstrate openness to cross-community relationships. This data is especially important given the increasing tribalism and division that has emerged because of Brexit. Participants were recruited by contact and relationships with key informants actively involved in the Project. Snowball sampling provided many more participants who shared their Ulster Project experiences and how they made meaning of these experiences. Purposeful sampling via sign-up sheets secured individual interviews after each homogenous focus group. Those interested in meeting individually were able to sign up for individual interviews. The attention focused on the use of culturally respectful, ethical dialog when asking open-ended questions in a semi-structured interview format. Further, interacting with participants with unconditional positive self-regard allowed them to feel accepted regardless of their responses. Congruent with these guidelines, the sample consisted of a mix of Catholics, Protestants, men, and women eighteen or older who participated in the Ulster Project from the inception. Part of the inherent trust was due to the significant measures taken with regard to safety, confidentiality, and specifics about participants. The towns and its inhabitants who were, and are still active with the Project, all are known to each other. As a result, specific methodological details are intentionally excluded, as it would identify individuals and communities, placing them at risk. Further, because of the continued tension and potential for violence, focus groups were homogenous, either Catholic or Protestant, and meetings held in common cultural areas. Due to on-going cultural segregation, it would have been perilous if participants were observed coming/going from meeting venues outside of their communities.

\section{Discussion}

The data from the focus groups and individual interviews presented evidence of a progression and permanent change in participants' attitudes about The Other. These changes occurred because of 
participating in this cross community organization. Finally, suggestions for the continuous need for the Project to evolve in order to remain viable in an effort to offset the continuing influences of dissident Unionist and Nationalist paramilitary organizations. In addition, the risks of Brexit to Northern Ireland looms large as compared to any other region or nation in the UK. These threats are complicated and multi-layered. Brexit prompts significant fears in Northern Ireland. These fears include, but are not limited to economic consequences, reviving the hard border between the Republic of Ireland and Northern Ireland. Additionally, concerns about reinstituting the hard border will be multifaceted, significantly affecting trade, the potential for agriculture being decimated, and the substantial increase in tribalism and additional division. Further, the impact on political stability, not to mention the implications for the peace process and the Good Friday Agreement (Braniff \& Whiting, 2017;Sinn Féin, 2017). Additionally, the implications of Brexit may have significant consequences to the viability of crosscommunity programming. This is due to the significant increase in tribalism and division in the wake of the passage of Brexit.

Despite these concerns, themes emerging from the groups and interviews consisted of personal growth and the role of change agent to their communities. These themes, along with the consistent acknowledgement of short and long-term positive impacts the Project has had on the lives of the Northern Irish alumni. For example, M from Bainbridge expressed: "Before I went to America, I have always been brought up to be decent, but still at the same time, when you are young, you can be a wee bit bitter towards the Otherside purely for being young and being ignorant. If that makes sense and you are very, sort of prone to what other people say; you are very impressionable. You hear things in the news and your friends say something, you get a very bad image of the Otherside, or if you hear that someone got shot or somebody got blew up or there was a bomb scare or whatever. You just automatically become, what's the word, you take a side, but we are Protestant, so at times, they seem brash, but obviously, they are not all like that. Prior to America, I don't think I had any Catholic friends."

Additionally, participants repeatedly noted they lacked knowledge of those from differing faiths prior to their involvement, mentioning certain negative stereotypes. After attending an introductory meeting before the start of the Project in a chapel (i.e., Catholic Church), Protestant respondents reported a "sense of betrayal," and "actually feeling sick" being inside. However, participants universally noted a transformation in their perceptions as they began to get to know each other. Specifically, J from Coleraine reflected: "I can remember we met up at St. Joseph's. It was our first or second meeting. We were all together and our parents were there. I think that was so good our parents were there a couple of times for a couple of meetings, which was great. Things that my Da [father] would never have heard, it was just great. It not only brought me, it got my family involved as well. That there informs you for the rest of your life, there would be no amount of money."

Conversely, for most Protestants, leaving the EU was viewed as something to escape, "taking back control, and getting our country back." However, for Northern Irish Catholics, the counterpoint is "waking up in a different country." This sentiment has unique political gravity and increasing the divide between Unionists and Nationalists (Gormley-Heenan \& Aughey, 2017). Membership in the EU not only helped build a stronger economy for Northern Ireland, but also created the path towards the official end of the Troubles. As a result of the EU membership, stronger relationships between Britain and Ireland were forged. Brexit and the dissolution of the Northern Irish power sharing government is now at the forefront of anxiety among its inhabitants plagued by historical uncertainty, tribalism, sectarian violence and division. A Police Service of Northern Ireland (PSNI) officer, shared: "One bullet to the head of a high profile person will start this whole thing again, it's like a tinderbox right now as you can see with the flag issue. We have a whole tribal problem in this country. I think once we have two tribes in a country that are, been allowed to stay separate, I think you're always going to have problems." According to the Independent (2017), the former Irish Prime Minister, Bertie Ahern who helped negotiate the 1998 Peace Accord warned that Brexit poses dangers to the overall stability of the peace process and the continued pursuit to diversify Northern Ireland. Ahern noted that Brexit could once again lead to a hard border between the North and the Republic of Ireland. He shared, "Any kind of physical border, in any shape, is bad for the peace process. It psychologically feeds badly to the Nationalist communities (Independent, 
2017)." Further, Ahern said the Good Friday Agreement was about "removing barriers" and "integrating across the island." Reinstating a physical barrier would have "a destabilizing effect" (Independent, 2017). The increase in tribalism was noted even prior to the proposal to leave the European Union. Another Project participant observed rising tensions due to the increasing political influences of Nationalists in the power sharing government: "You can see it in the Protestant community now, and they're feeling very, very aggrieved, so it's nearly switching around. When it (sectarian violence) kicked off again in the 60s and 70s, it was the Catholic community that was feeling aggrieved. As a Catholic, I feel they have no right to be aggrieved, but because they've nearly had it their own way for so long and things are starting to even up a wee bit, they're feeling aggrieved because they feel as if they're losing." However, despite the rising tensions, tribalism, and divisiveness, the importance of maintaining cross-community programming is significant. S from Banbridge described a positive change in her views of the Other: "Getting a chance, an opportunity to spend time with the Catholic people. You get to know them. It allowed me to open my eyes to see they're just the same as us. I don't know if that situation to spend that much time could've happened if I hadn't went to America. The schools I went to were mostly Protestant, so I don't know if that situation would have ever came later. To spend that much one-on-one time with them, it gave me a chance to talk to them and discover they're just the same as us, and then, how was I different? I came back and then I painted them all with a different brush instead of all being a brush maybe linked to the IRA [Irish Republican Army]. They're just nice people, maybe a few bad eggs about, but chances are I won't run into them. So you came out, looking at them very differently."

\section{IMPLICATIONS OF THE ULSTER PROJECT AND BREXIT}

The benefits and impact of the Ulster Project closely correlates with the theme of hope for the future of a peaceful Northern Ireland, which is in flux due to Brexit. Participants used words and phrases such as "life-changing, long-term friendships" with the Other. Further, terms such as "changed perceptions" when describing the meaning of their experiences was consistent in interviews. Consistently, connections with the Other were acknowledged as an integral part of the Project being a life-changing experience. Meeting those with differing backgrounds and faiths shattered long-held preconceived ideas about people they never met. Participants acknowledged they would have never met those of differing faiths and social (class) backgrounds if they did not participate in this cross-community project. Nearly all shared that these friendships have continued many years later, contributing deep meaning to their lives. Further, these friendships have also included marriages, as well as mixed marriages (those of differing faiths) because of participation in the program.

Older respondents, as well as recent participants noted that experiences in the Ulster Project influenced their career decisions such as opportunities to teach in cross-community and/or integrated schools, working in the government, and attending universities that are more diverse. Further, the realization of the strength of the Project often evolved with a deeper appreciation over time. Developing a greater understanding and a sense of respect for other religions, opinions, and perspectives was identified as a strong and valuable point, described as "eye-opening to what is truly important (Individual Interview)." The values enhanced during various learning opportunities, especially among older respondents were most often shared with their children. This is evidenced by participants having a greater likelihood to enroll their children in integrated education. As a result, this challenged generational family stories perpetuating negative stereotypes of the Other.

Integrated education is the best way forward to achieve a lasting peace. The current body of research supporting interactions with the Other through cross-community and educational programs supports this view. Further evidence indicates these cross-community connections correlate positively to increasing goodwill, tolerance, decreasing negative stereotyping, and creating friendships. This is currently in flux due to the amplified divisiveness and tribalism resurfacing because of the impending plan for the UK to leave the EU. This divisiveness and tribalism, 'for or against' has not been as intense since the Troubles. However, understanding the power of cross community programs such as the Ulster Project can guide similar programs and improve the continued service delivery, even in these divisive times in Northern 
Ireland. Subsequently, the individual tactics will be inconsequential. However, the degree which encourages and allows the Northern Irish to continue promoting and experiencing cross-community involvement and relationships in a potentially post-Brexit society.

\section{The British Exit}

The vote for the UK to leave the EU has significant consequences for the relationships within the island of Ireland as well as that between Ireland and the UK. The overarching concern is the realization of a return of a hard border between the North and the Republic of Ireland. According to Daly, Dolan, \& Brennan (2018) there will be a return to violence in Northern Ireland if there is a re-installation of a hard border that will include custom and security checks because of Brexit. The only issue, the authors contend is the scale of the violence. Northern Irish citizens no longer have to endure the violence of the Troubles, but there still exists an environment with residual issues related to that violent turbulent time. However, inroads have been made, especially within cross-community programs connecting young people of differing faiths and ideologies.

With the impending implementation of Brexit, there also could a referendum on the unification of the island of Ireland. This has major implications for all, but notably for the Protestant/Unionist communities. Given how Protestants feel about the potential of this referendum, a return to violent extremism not seen since the Troubles is a real possibility (Daly, Dolan, Brennan, 2018). The authors suggest that all indications are, without direct efforts to engage and connect Northern Irish citizens of all backgrounds, youth and others could be quickly drawn into the conflict and escalating extremism. The new Troubles will be due to the re-establishment of a hard border and a potential referendum for the six counties in the North to reunite with the twenty-six counties in the Republic of Ireland if the UK leaves the EU (Daly, Dolan, Brennan, 2018).

The value of cross-community programming cannot be understated, especially with Northern Irish youth. The potential of 'history empathy' education is a key tool to fuel understanding and healing in school and community contexts. Further, the role of involving diverse youth in the process has specific potential in motivating young people towards continuing the peace building process in Northern Ireland (Daly, Dolan, Brennan, 2018).

\section{CONCLUSION}

Since the inception of the Ulster Project, many other cross community organizations have emerged within Northern Ireland. Women's Caring Trust, now known as Hope for Youth is just one example that incorporates a variety of activities and opportunities with a diverse group of intercommunal young people. This program supports youth, eleven to eighteen years of age, particularly from disadvantaged areas. The group members learn to work together, acquire new skills, and build friendships in a safe environment (Hope for Youth, 2019). The philosophy of the organization is "by giving young people a glimpse of a less fractured society - focusing on cross community activities that fosters teamwork and creativity - especially in the field of music, art, drama and the great outdoors - we aim to help break the cycle of violence that has troubled Northern Ireland for decades" (Hope for Youth 2019). In 2018 alone, ten substantial grants were awarded across Northern Ireland to support cross community curriculums. Some notable examples include summer programming for younger children to incorporate social awareness and team building. "The Whistle Project," for example explores social attitudes, focusing on relationship building while painting murals as a specific outcome.

One of the oldest peace and reconciliation organizations within Northern Ireland is known as Corrymeela founded by a survivor and prisoner of war in World War II (corrymeela.org, 2019). Currently, there are forty full time staff with dozens of volunteers. These staff and volunteers have worked with approximately eleven thousand people participating in this residential program since its inception (corrymeela.org, 2019). The philosophy of their program is "to transform division through human encounters" (corrymeela.org, 2019). This includes involving schools every year to participate in 
various activities. Involving non-integrated schools and segregated youth in cross community programs is significant and correlates with the themes of Ulster Project participants.

Most participants feel that integrated schools are the key to real and long-lasting peace. P, from Coleraine, as well as most respondents confirmed, "Real, and lasting change will only happen with having integrated education." Noting that dissonance may exist between participants' Project and home experiences, he elaborated: "That's what makes it more difficult, because even what they learn at the age of 15, what they're hearing, what they're experiencing, they're having to go back to live with reality. It's a very different place from a nice, fun, supportive environment. There's a lot of that goes on in the hard areas too, there is a lot of cross community work, but desegregation, school desegregation I think is key."

Similarly, D from Banbridge shared that she became very open-minded and independent with regard to mixing and sensitivity with cross community involvement and integrated education: "Oh, very much so. I became very independent, I mean the religious wise, as my children went to mixed schools from the start right through because of it (The Ulster Project). I was very reluctant at the start of it to send them to the Academy (integrated school). I actually talked to one of the Project leaders who went with us about it before I sent them there. They went there and, I have to be honest, they loved it, the best thing that could've happened to them, to be honest."

Despite the post-peace agreements in Northern Ireland, there continues to be a division of society within the segregated education system. However, there has been an increase in integrated education. For example, in 2001, 5.6\% of Northern Irish youth attended an integrated school. By 2007, it increased to $7.2 \%$. As of 2018, 8.6\% of students are attending integrated schools (The Economist, 2018). There is general agreement that desegregating schools will transform the division that continues to exist. However, there has been inconsistent progress reforming the educational system since the peace agreement. This proposal is even more daunting given the rise in tribalism and divisiveness with Brexit forthcoming. Until the government and educational system can create a mutually agreeable proposal for a shared curriculum and education, significant barriers remain in place. This is due, in part to a lack of infrastructure in Northern Ireland creating opportunities for religious education (such as the Confraternity of Christian Doctrine (CCD) offered to Catholic school-aged youth attending public school in the United States) outside of a secular school district (Schiaparelli, 2015). Until the factors impeding integrated education can be overcome, Northern Ireland will continue to need cross community programming to combat the consequences of stereotypes and "othering." The proposed implementation of Brexit will significantly complicate these cross community endeavors. Connecting with marginalized youth in order to understand their challenges could prove vital in motivating them away from violence in a Brexit society. These challenges will be exacerbated by a possible referendum for the six counties in the North leave the UK and join with the Republic of Ireland. Further, increasing empathy educational programs in schools is essential, as they have proven effective in decreasing extremism and violence. As a result, these diverse programs increase social supports and positive civic engagement, thus will mitigate the effects of Brexit and the possible referendum for the six counties in the north to reunite with the twenty-six counties in the south, creating one Ireland, thus remaining in the European Union.

\section{REFERENCES}

Archick, K. (2019). Currrent Issues and Current Challenges in the On-going Peace Process. Washington D.C.: Congressional Research Service. Retrieved April 9, 2019, from https://crsreports.congress.gov/

BBC.com. (2012, July 11). Retireved from https://www.bbc.com/news/uk-northern-ireland-18769781. BBC News. (2019, May 8). Retrieved from www.bbc.co.uk: www.bbc.co.uk Braniff, M., \& Whiting, S. (2017). Deep Impact, the Fiction of a Smooth Brexit for Northern Ireland. Juncture, 23(4), 249-252. doi: https://doi.org/10.1111/newe.12022

Coon, D., \& Mitterer, J. (2009). Psychology, Models for Active Learning (Vol. 4). Belmont, California: Wadsworth Cengage Learning. 
Corrymella.org. (2019). Retrieved from https://www.corrymeela.org/programmes/sectarianism.

Crick, N., \& Dodge, K. (1996). Social Information-Processing Mechanisms in Reactive and Proactive Aggression. Child Development, 67, 993-1002. doi: doi:10.1111/j.1467-8624.1996.tb01778.x

Daly, M., Dolan, P., \& Brennan, M. (2018). Northern Ireland Returning to Violence as a Result of a Hard Border due to Brexit or Rushed Border Poll, Risks for Youth.

Dunn, S., \& Dawson, H. (2000). An Alphabetical Listing of Word, Name and Place In Northern Ireland and the Living Language of Conflict. Ceredigion, Wales, United Kingdom: The Edwin Mellen Press.

Fenton, S. (2015, August 4). As Northern Ireland's flag debate rages on, could a new neutral design be the answer? Retrieved from https://www.newstatesman.com:

https://www.newstatesman.com/politics/2015/08/northern-irelands-flag-debate-rages-could-newneutral-design-be-answer

Gillespie, P. (2019, March 16). The Irish Times. Retrieved from The Relationship between Ireland and Britain will Never be the same agan: https:/www.irishtimes.com/opinion/the-relationshipbetween-ireland-and-britain-will-never-be-the-same-again-1.3827782

Gormley-Heenan, C., \& Aughey, A. (2017). Northern Ireland and Brexit: Three effects on 'the border in the mind'. The British Journal of Politics and International Relations, 19(3), 497-511. doi:10.1177/1369148117711060

Hope for Youth. (2019). Retrieved from http://hopeforyouthni.com/who-we-are.

Independent. (2017, February 13). Brexit puts Northern Ireland peace process at risk, Bertie Ahern warns, p. 14. Infotrac Newsstand. Retrieved from http://link.galegroup.com.aurarialibrary.idm.oclc.org/apps/doc/A480947250/STND?u=auraria_m ain\&sid=STND\&xid=f9. London, England. doi:GALE $\mid$ A480947250

Kelly, B. (2019, April 30) Retrieved from https://www.independent.co.uk: https://www.independent.co.uk/news/uk/politics

Lemerise, E., \& Arsenio, W. (2000). An Integrated Model of Emotion Processes and Cognition in Social Information Processing. Child Development. Child Development, 107-118. doi:doi:10.1111/14678624.00124

Little, A. (2011, November 2). The European Capital of Terrorism: Belfast. Northern Ireland. (M. Moynihan, Interviewer)

Marshall, M. (1996). Sampling for Qualitative Research. Family Practice, 13, 522-525.

Merrilees, C., Cairns, E., Taylor, L., Goeke-Morey, M., .Shirlow, P., \& Cummings, E. (2013). Social identity and youth aggressive and delinquent behaviors in a context of political violence. Political Psychology, 34(5).

Schiaparelli, K. (2015). Divided Society, Divided Schools, Divided Lives: The Role of Education in Creating Social Cohesion in Northern Ireland. Clocks and Clouds, 6(1), 1.

Shepard, L. (2007). Exposure to Community Violence and Political Socialization Among Adolescents in Northern Ireland. Policy Features in Education, 5(3), 386-400.

Sinn Féin. (2017, May). Fighting the Economic Impact Of Brexit in NI. How Ireland and the EU can fight the economic impact of Brexit north and south. Retrieved from https:/www.sinnfein.ie/brexit: https://www.sinnfein.ie/files/2017/FightingEconomicImpactOfBrexit1.pdf

Smyth, M., \& Campbell, P. (2005). Young People and Armed Violence in Northern Ireland. Belfast: Institute for Conflict Research.

Ulster Project International. (2019, May 15). Retrieved from http://www.ulsterproject.org/creation.htm: http://www.ulsterproject.org

Ulsterproject.org. (2012). Retrieved from http://www.ulsterproject.org/what.html: http://www.ulsterproject.org/what.html

Ulsterproject.org. (2019, July 14). Retrieved from http://www.ulsterproject.org/what.html: http://www.ulsterproject.org/ 